\title{
HIBERNATING BUMBLE BEES AT THE PAS, MANITOBA
}

\section{NALTER KRIVDA, Box 864, The Pas, Manitoba. R9A $1 \mathrm{~K} 8$}

It is well known that bumble bees ibernate. The fertilized queens in the all of the year find suitable refuge for ie winter. Here they freeze almost solid. this condition they pass the winter. In le spring as the ambient temperature ses, they revive, leave their hiding laces and start to feed on the pollen hd nectar on the first pussy willow lossoms. This is likely their first food. oon after, they start new broods. This art of the life history is rather well hown.

It is somewhat of a puzzle however, st where bumble bees pass the winter. he nests of mice are often suggested a likely place; old sawdust piles are so listed as likely spots. Hibernating rectly in the ground is not mentioned. northern areas and beyond tree line, e soil is the only available location. ere in the wilder habitats, humocky, eaty soil is likely favoured.

It is not known evidently that solitary umble bees overwinter in gardens in e ground.

Over the past 30 years and more, I ave noted that bumble bees are found potato hills in September when the tatoes are dug. I have collected such ecimens and preserved them in my sect collections.

When the hill is disturbed as the tatoes are dug, the bees often fall on eir backs. In bright sunny weather, ey will buzz loudly, soon after being ig out of the loose, friable soil. Some in even fly off. In dull, cold autumn cather they stay torpid and dormant id can be carried in the hand.

This year, on 10 September, I had the eat good fortune to observe a queen imblebee flying among potato hills in garden looking for a likely hiber- nating location. After a few minutes of explorations, she landed, walked up a potato hill and entered the top of the hill just where the potato vines emerged from the ground. She began pushing into the soft soil head first and using the first pair of legs to help her along. In less than a minute she was out of sight. The soil continued to heave briefly as she dug. Soon this stopped as she penetrated more deeply. The following day I dug her out. She had penetrated three inches into the soil. Over the next eight days as 700 hills of potatoes were dug, seven queen bees were found. Three have been preserved as specimens and labelled as being found in potato hills. The other four were set free. All were of one species the Common Black and Yellow Bumblebee. Hibernation in soil is hereby established. This may help explain why other, black species of Bombus can survive on the Islands of the high arctic where the only place to hibernate is the soil. This is the ecological winter niche of bumblebees.

It should be noted that $1 \%$ of the potato hills had hibernating bees. A farmer's field of thousands of hills can accommodate the future mothers of entire bumblebee populations.

It is early enough in the year for the disturbed queens to find new winter quarters after having been driven out by potato diggers. A late cold and wet season may kill many exposed queens. This needs more observation.

The habit of bumblebee queens attempting to hibernate in potato hills may adversely affect bumblebee populations in areas devoted to potato farming. This may have an indirect effect on seed set of wild plants locally and also on plants such as field peas, needing bee pollination. 